\title{
Lipase-catalyzed biodiesel production from waste activated bleaching earth as raw material in a pilot plant
}

\author{
Enoch Y. Park ${ }^{\mathrm{a}^{*}}$, Masayasu Sato ${ }^{\mathrm{b}}$, Seiji Kojima ${ }^{\mathrm{b}}$
}

${ }^{\text {a }}$ Laboratory of Biotechnology, Integrated Bioscience Section, Graduate School of Science and Technology, Shizuoka University, 836 Ohya Suruga-ku, Shizuoka 422-8529, Japan

${ }^{\mathrm{b}}$ Intellectual Property Department, Mizusawa Industrial Chemicals Ltd., 1-13-6

Nihonbashimuromachi, Chuo-ku, Tokyo 103-0022, Japan

\footnotetext{
* Corresponding author. Tel. \& fax: +81-54-238-4887

E-mail address: yspark@agr.shizuoka.ac.jp (EY Park)
} 


\section{Abstract}

2 The production of fatty acid methyl esters (FAMEs) from waste activated bleaching

3 earth (ABE) discarded by the crude oil refining industry using lipase from Candida

4 cylindracea was investigated in a 50-L pilot plant. Diesel oil or kerosene was used as an

5 organic solvent for the transesterification of triglycerides embedded in the waste ABE.

6 When $1 \%(\mathrm{w} / \mathrm{w})$ lipase was added to waste ABE, the FAME content reached $97 \%(\mathrm{w} / \mathrm{w})$

7 after reaction for $12 \mathrm{~h}$ at $25^{\circ} \mathrm{C}$ with an agitation rate of $30 \mathrm{rpm}$. The FAME production rate

8 was strongly dependent upon the amount of enzyme added. Mixtures of FAME and diesel

9 oil at ratios of 45:55 (BDF-45) and 35:65 (BDF-35) were assessed and compared with the

10 European specifications for biodiesel as automotive diesel fuel, as defined by pr EN

11 14214. The biodiesel quality of BDF-45 met the EN 14214 standard. BDF-45 was used as

12 generator fuel, and the exhaust emissions were compared with those of diesel oil. The CO

13 and $\mathrm{SO}_{2}$ contents were reduced, but nitrogen oxide emission increased by $10 \%$. This is

14 the first report of a pilot plant study of lipase-catalyzed FAME production using waste

$15 \mathrm{ABE}$ as a raw material. This result demonstrates a promising reutilization method for the

16 production of FAME from industrial waste resources containing vegetable oils for use as

17 a biodiesel fuel.

18

19 Key words: Activated bleaching earth; Biodiesel fuel; Candida cylindracea lipase; Fatty 20 acid methyl esters; Pilot plant 


\section{Introduction}

Biodiesel (fatty acid methyl ester; FAME), which is synthesized by the transesterification of vegetable oils or animal fat sources, is an attractive alternative to diesel fuel because it is produced from renewable resources (Clark et al., 1984). Europe leads worldwide production with more than 1.6 million tons of biodiesel produced in 2002 (Körbitz et al., 2003). With over 10 years of commercial use in Europe, biodiesel has now proved its value as a diesel engine fuel. When biodiesel was tested in a diesel engine using the Environmental Protection Agency (EPA) heavy-duty engine cycle, particulate matter, total hydrocarbons, and carbon monoxide were reduced, but nitrogen oxides $\left(\mathrm{NO}_{\mathrm{x}}\right)$ were increased (Schumacher et al., 1996). Moreover, a $20 \%$ blend of biodiesel oil improved peak thermal efficiency by $2.5 \%$ and substantially reduced smoke opacity values (Agarwal and Das, 2001). The biodiesel market is now expected to grow rapidly to meet the new European Directive volume target of $5.75 \%$ biofuels in the transport sector by 2010 .

Commercial biodiesel production involves the use of strong alkalis or acids as chemical catalysts in aqueous reactions at high temperatures. This process is cost effective, but requires extra purification steps to remove glycerol, water, and impure by-products from FAME (Bouaid et al., 2005).

Recently, a lipase-catalyzed esterification of various kinds of vegetable oils using an organic solvent or a solvent free system was studied as an environmentally friendly process (Dossat et al., 2002; Fukuda et al., 2001; Lara and Park, 2004). We investigated the application of waste activated bleaching earth $(\mathrm{ABE})$ in the production of biodiesel using lipase in an organic solvent (Lara and Park, 2003; Lara and Park, 2004; Kojima et al., 2004; Park and Mori, 2005) or a solvent-free system (Du et al., 2006). ABE is one of the most commonly used absorbents due to its high absorption capacity. In the vegetable 
1 oil refining process, the upgrading of crude oils of vegetable origin requires the use of

2 ABE for the removal of carotene, chlorophyll, and other components formed during the

3 refining process (e.g., phosphatides and soaps). Nearly $35 \%$ to $40 \%$ of the weight of

4 waste ABE is vegetable oil (Lara and Park, 2003), a substrate that could be utilized for the

5 synthesis of a wide range of products to be used as bulk chemicals. Lipase from Candida

6 cylindracea has its highest activity in $n$-hexane only when waste ABE is present, and

7 more than $78 \pm 6 \%(\mathrm{w} / \mathrm{w})$ FAME is attained during the first $4 \mathrm{~h}$ of the reaction (Lara and

8 Park, 2004). Using diesel oil as an organic solvent, $3 \mathrm{~h}$ is sufficient to obtain a yield of

9 approximately $100 \%$ FAME from waste $\mathrm{ABE}$ in the presence of $10 \%$ lipase. Kerosene is

10 also a good organic solvent for the esterification of triglycerides embedded in waste ABE

11 (Kojima et al., 2004).

The objective of the present study was to investigate biodiesel production on a pilot plant scale using waste $\mathrm{ABE}$ as a raw material with methanol and lipase as the catalyst.

\section{Materials and methods}

\subsection{Materials}

Lipase OF from Candida cylindracea was purchased from Meito Sangyo Co. Ltd. (Nagoya, Japan). Mizusawa Chemical Industries Co. (Niigata, Japan) provided waste ABE containing $35 \%$ to $40 \%$ palm or rapeseed oils by weight. Methanol was of analytical grade, and was purchased from Wako Pure Chemical Industries (Osaka, Japan). No. 2 grade diesel oil and kerosene were used as solvents in the synthesis of FAME. The standards for the gas chromatography (GC), methyl pentadecanoic acid and the vegetable oils, were from Sigma Chemical Co. (St. Louis, MO). 
1 The newly designed and constructed pilot plant equipment, developed to produce

2 FAME from waste ABE using lipase as the catalyst, is depicted in Fig. 1. It is a batch-type

3 operating reactor equipped with a cooling jacket for temperature control. The size of the

4 reactor is $0.68 \mathrm{~m}$ (outer diameter) by $0.66 \mathrm{~m}$ (height), its total capacity is $50 \mathrm{~L}$ with a

5 working volume of $30 \mathrm{~L}$, and it was constructed of SUS304 and SUS316 stainless steel.

6 Agitation was controlled by a motor (Sumitomo Cyclo CNVM05-6100-59, Sumitomo

7 Heavy Ind. Ltd., Tokyo, Japan). Temperature was controlled, via a temperature controller

8 (B301, Yamato Scientific Co. Ltd., Tokyo, Japan), by circulating cooling water into the

9 jacket of the reactor. At the end of the reaction, FAME was recovered using a filter press,

10 with a purging air pressure of $0.5 \mathrm{MPa}$.

11 The pilot plant consists of a mixture of waste ABE and methanol, a reactor for the transesterification of the vegetable oil, and a filter press for separation of the mixture of

13 FAME and solvent. Premixed waste ABE (stream 1) and methanol (stream 2) were added

14 to the reactor together with solvent (stream 3), and then lipase (stream 4) was added. The

15 addition of lipase to the reactor initiated the transesterification reaction. The reaction

16 temperature was varied from $15^{\circ} \mathrm{C}$ to $55^{\circ} \mathrm{C}$, and the agitation rate was fixed at $30 \mathrm{rpm}$.

17 After the reaction, biodiesel (stream 5) was recovered using a filter press, and filter cake

18 (stream 6) remained as waste materials. Waste ABEs containing either palm oil or

19 rapeseed oil were used as raw materials.

\subsection{FAME production}

A typical reaction mixture consisted of $25 \mathrm{~kg}$ of waste $\mathrm{ABE}$ (containing approximately $8.8 \mathrm{~kg}$ palm oil), $10.2 \mathrm{~kg}$ solvent, $250 \mathrm{~g}$ C. cylindracea lipase (added as a

24 powder), and $1.17 \mathrm{~kg}$ methanol (1:3.5 oil to methanol molar ratio). Optimal temperature 
1 of C. cylindracea lipase is $30-40^{\circ} \mathrm{C}$. After the reaction, the FAME plus organic solvent

2 mixture was filtered using a filter press and stored in a storage tank as biodiesel fuel. The

3 filter cake containing lipase and vegetable oil-free waste ABE was stored in the storage

4 tank as the final waste. After the reaction, part of the produced FAME, solvent, and

5 glycerol (a by-product) were readsorbed onto the vegetable oil-free waste ABE, which

6 remained as waste. Because the reaction conditions, including wABE, lipase, methanol,

7 and rapeseed oil concentrations, are known at time zero, the initial FAME production rate

8 was defined as,

Initial FAME production rate $(\mathrm{mM} / \mathrm{min})=\left[\frac{d P}{d t}\right]_{t=0}$

where $P$ and $t$ denote produced FAME concentration and reaction time $(<5 \mathrm{~h})$,

11 respectively.

12 2.4. Analytical methods

\subsubsection{FAME}

Products from the enzymatic reaction mixtures were prepared by adding $300 \mu \mathrm{L}$ of $n$-hexane to a $500-\mu \mathrm{L}$ aliquot of the homogenous suspension and mixing for $30 \mathrm{~s}$. For quantitative determinations, a specified amount of sample was redissolved in $1 \mathrm{~mL}$ chloroform and a 4- $\mu \mathrm{L}$ aliquot was injected into a gas chromatograph (GC-14B, Shimadzu, Kyoto) coupled with a glass column (3 $\mathrm{mm}$ x $2 \mathrm{~mm}$ ) packed with 5\% Advans DS on 80/100 mesh Chromosorb W (Shimadzu, Kyoto) and a flame-ionized detector. The

20 detector and injection port temperatures were $250^{\circ} \mathrm{C}$ and $240^{\circ} \mathrm{C}$, respectively, and an

21 isothermal column temperature of $190^{\circ} \mathrm{C}$ was maintained. All GC measurements were

22 performed in triplicate and the concentrations were determined from standards of fatty

23 acid methyl esters and by utilizing methyl pentadecanoate as an internal standard.

24 Standard FAME was prepared by transesterifying the vegetable oil directly with $2 \%$ 
1 sulphuric acid-methanol solution at $50^{\circ} \mathrm{C}$ overnight. The FAME content is defined as the

2 weight ratio of the amount of total FAME synthesized in the enzymatic hydrolysis to the

3 weight of vegetable oil contained in the waste ABE. The FAMEs in the samples

4 containing diesel oil or kerosene were quantified using previously prepared calibration

5 curves (Kojima et al., 2004). Various compositions of vegetable oil and chemically

6 transesterified FAMEs in fixed ratios in diesel or kerosene were prepared, and their total

7 FAMEs were quantified using GC. Using this data a calibration curve between the total

8 peak area of FAMEs and the ratio of chemically transesterified FAMEs was made. In this

9 case, we assumed that the difference in molecular weight between the vegetable oil used

10 and the total FAMEs is negligible; diesel oil or kerosene is inert in the FAME reaction and

11 is also equilibrated between the liquid and ABE phases. Two kinds of calibration curves,

12 for diesel oil 55\% and kerosene $65 \%$, were used for FAME measurements in this study.

2.4.2. Fuel analysis

Fuel analysis was commissioned to Idemitsu Techno Research Center (Sodegaura, 16 Chiba, Japan).

2.4.3. Fuel tests in a diesel generator

Exhaust emission tests using biodiesel produced in the pilot plant were performed over a 7-h period in a generator (S4S-E3DT, Mitsubishi, Tokyo, Japan) that has a 3331-cc piston displacement diesel engine with a rated load of $28 \mathrm{~kW}$. Emissions of $\mathrm{CO}, \mathrm{SO}_{2}, \mathrm{NO}$, $\mathrm{NO}_{2}$, and $\mathrm{NO}_{\mathrm{x}}$ were measured.

\section{Results}

\subsection{FAME production}


FAME production using waste ABE was measured in our laboratory in preliminary

2 studies (Lara and Park, 2003; Lara and Park, 2004 Kojima et al., 2004). Using optimized

3 reaction conditions (Kojima et al., 2004), a 97\% FAME yield was obtained with a

4 reaction time of $12 \mathrm{~h}$ (data not shown), an initial enzyme concentration of $1 \%(\mathrm{w} / \mathrm{w}$, waste

$5 \mathrm{ABE}$ ), an operating temperature of $25^{\circ} \mathrm{C}$, and an agitation rate of $30 \mathrm{rpm}$. FAME yield

6 increased with reaction time and reached $99 \%$ within $24 \mathrm{~h}$. The material balance showed

7 that $31.4 \%$ of reactant was converted to biodiesel fuel in the liquid phase and $68.2 \%$ of

8 reactant was converted to waste $\mathrm{ABE}$ in the solid phase (data not shown). Ninety-six

9 percent of input materials were recovered as solid and liquid products. The filtrate was a

10 mixture of FAME and diesel oil at a ratio of 45:55, namely BDF-45, because the diesel oil

11 was not separated from the FAME. The filter cake contained unreacted vegetable oil,

$12 \mathrm{ABE}$, enzyme, glycerol, FAME, and solvent. Because the waste ABE adsorbed vegetable

13 oil before the transesterification reaction and also readsorbed part of the FAME and

14 glycerol, and some of the solvent, as it reached equilibrium with the liquid phase at the

15 end of the reaction. After the reaction, there was very little vegetable oil adsorbed to the

16 waste $\mathrm{ABE}$ (stream 5), judging from an extraction with hexane. Therefore, the waste

$17 \mathrm{ABE}$ (stream 5) was designated vegetable oil-free ABE.

18 The amount of enzyme strongly affected the FAME production rate. The FAME

19 production rate was proportional to the amount of enzyme used in this process with a high

20 correlation coefficient (data not shown), which suggests that FAME production is

21 strongly governed by the enzyme concentration.

Reaction temperatures in the range of $15^{\circ} \mathrm{C}$ to $55^{\circ} \mathrm{C}$ were evaluated for enzymatic

23 production of FAME using waste ABE. Because this process is heterogeneous, the effect

24 of reaction temperature might be a critical factor for efficient FAME production. At

25 temperatures between $15^{\circ} \mathrm{C}$ and $20^{\circ} \mathrm{C}$, the initial FAME production rate was $5.7(\% / \mathrm{h})$, 
1 and $98 \%$ FAME was obtained with a reaction time of $24 \mathrm{~h}$ (Fig. 2). In the range $25^{\circ} \mathrm{C}$ to

$245^{\circ} \mathrm{C}$, the initial FAME production rate was $8.1(\% / \mathrm{h})$, and $97 \%$ FAME was obtained with

3 a reaction time of only $12 \mathrm{~h}$. At $55^{\circ} \mathrm{C}$, however, the final FAME content was only $79 \%$,

4 even though this temperature produced the highest FAME production rate $(19.8 \% / \mathrm{h})$.

5 This indicates that high temperatures inactivated the enzyme. Therefore, this result

6 suggests that room temperature is suitable for a high conversion rate to FAME.

\subsection{Characterization of the FAME}

Some of the important parameters of biodiesel produced in this experiment are

10 shown in Table 1. For experiments no. 1 through no. 5, the FAME was mixed with diesel 11 oil at a ratio of 45:55 (BDF-45), while for no. 6 the FAME was mixed with diesel oil at a ratio of 35:65 (BDF-35). FAME was not separated from the diesel oil, but was harvested as a mixture with diesel oil. Although samples of waste ABE containing palm oil and diesel oil were used, the properties of BDF-45 in the process using $1 \%(\mathrm{w} / \mathrm{w})$ enzyme were similar to each other, except for the pour point and $10 \%$ residual carbon amount.

16 The fuel specifications, including $10 \%$ residual carbon amount, cetane number, and sulfur 17 concentration, comply with the EU Draft standard prEN 14214. The sulfur concentration 18 was lower than that specified in EN 14214. Furthermore, the results of experiment no. 6 19 demonstrate that kerosene can be used instead of diesel oil. Density, cetane number, and 20 flash point deviated slightly from those of the standard specifications (EN 14214).

21 Therefore, if kerosene is used as the solvent, this process requires some improvement or 22 modification to fully comply with the EN 14214 standard.

The FAME obtained in this experiment was used as generator fuel. The exhaust gas 
1 was compared with that obtained using diesel oil as fuel during an operating time of $7 \mathrm{~h}$

2 (Fig. 3). The $\mathrm{CO}$ and $\mathrm{SO}_{2}$ emissions were reduced for FAME compared with no. 2 diesel

3 oil. FAME had the greatest maximum reduction in the $\mathrm{SO}_{2}$ concentration. There was no

4 difference in the $\mathrm{NO}_{2}$ concentrations between FAME and diesel oil. The $\mathrm{NO}$ and $\mathrm{NO}_{\mathrm{x}}$

5 emissions of FAME were higher by approximately $10 \%$.

\section{4. Discussion}

This is the first report of the utilization of waste ABE for FAME production by

9 lipase-catalyzed transesterification on a pilot scale. With water as the solvent, the

10 vegetable oils embedded in waste $\mathrm{ABE}$ are difficult for the lipase to access to achieve

11 esterification, resulting in a yield of 55\% (w/w) FAME (Lara and Park, 2003). On the other hand, an organic solvent effectively acts to improve the FAME conversion from the vegetable oils embedded in waste $\mathrm{ABE}$ and facilitates the generation of the active conformation of lipase, which contributes to the marked improvement in FAME production, a yield of almost 100\% (w/w) within 5 h (Lara and Park, 2004). When ABE was present among the reactants, there was very little free vegetable oil and methanol in

17 the solvent (n-hexane) because the vegetable oil was embedded in the ABE and methanol 18 has low solubility in organic solvents (Park and Mori, 2005). However, lipase acts as a catalyst in the solid phase of $\mathrm{ABE}$ and converts the dissolved and adsorbed vegetable oil to FAME. ABE may also play an important role in the activation of lipase, probably due to the interaction of its functional groups with those in the enzyme that may invoke conformational changes. The interfacial activation of the enzyme may be enhanced by its adhesion to the surface of ABE, leading to a more active conformation of the enzyme (lid opening) and to a better dispersion of the enzyme molecules. 
1 is one drawback of FAME production from waste ABE. Fossil fuel is a good alternative

2 solvent for FAME production because it can be blended with the FAME for practical use.

3 The stability of the enzyme in diesel oil was high and the FAME production rate in the

4 diesel oil was twofold higher than that in $n$-hexane (Kojima et al., 2004). Therefore the

5 use of diesel oil as a solvent in FAME production is an appropriate selection for the

6 utilization of waste ABE. From a process point of view, the FAME manufacturing process

7 (Fig. 1) using diesel oil is much simpler than that using an organic solvent, for example

$8 n$-hexane. This is because with diesel oil, a mixture of FAME and diesel oil is obtained

9 directly following filtration after transesterification. This mixture (stream 6 in Fig. 1) can

10 be used to make biodiesel fuel, if it is blended with diesel oil at an appropriate ratio. The

11 filter cake is a mixture of solid materials, lipase, and vegetable oil-free waste ABE that

12 partly adsorbs FAME, solvent, and glycerol (stream 5 in Fig. 1). Because the by-product

13 glycerol is adsorbed into the vegetable oil-free waste ABE, it is not necessary to separate

14 the glycerol from the FAME in this process.

15 It is difficult, however, to recover 100\% FAME from vegetable oil-free waste ABE.

16 The vegetable oil-free waste ABE cake contains approximately $14 \%$ FAME and $16 \%$

17 solvent on a weight basis. To recover 100\% FAME from the waste ABE requires

18 additional processing, i.e., extraction using $n$-hexane. The organic solvent might be

19 recovered and recycled during this process. Because the organic solvent is expensive, we

20 are planning to reuse the final cake as a solid fuel. The filter cake from this process

21 contains FAME and diesel oil, and is therefore easily shaped; thus, this cake is suitable as 22 a solid fuel.

23 Another disadvantage is that it is difficult to reuse the lipase. Because the lipase is 24 mixed with vegetable oil-free waste $\mathrm{ABE}$ as a cake, it is impossible to separate the lipase 25 from the final filter cake. The mixture of vegetable oil-free waste ABE and lipase, 
1 however, can be reused for the esterification of waste vegetable oil, as long as the lipase is

2 active. The waste edible oils from kitchens or restaurants are a good waste resource for

3 the reuse of the vegetable oil-free waste ABE containing lipase.

Fuel analysis (Table 1) demonstrated that FAME-containing diesel oil complies

5 with the biodiesel fuel specifications. Its flash point is lower than the EU standard EN

614214 , but is suitable for the JIS K 2204 standard. The 10\% residual carbon amount,

7 which is an important fuel specification, of run no. 5 (Table 1) was twofold higher

8 compared with the others. Kojima et al., (2004) reported that the $10 \%$ residual carbon

9 amount was in inverse proportion to the FAME content in the sample and, to comply with

10 the standard, the FAME content must be higher than 95\%. Although, the FAME content

11 of run no. 5 was higher than $95 \%$, the $10 \%$ residual carbon amount increased. This may

12 be due to difference in the amount of organic compounds including coloring materials

13 between palm oil and rapeseed oil. The wABE containing rapeseed oil contains higher

14 amount of coloring materials than palm oil, which may be one of the reasons. Other

15 parameters are in accord with those of EN 14214. The fuel test demonstrated that the

16 BDF-45 or -35 produced from the lipase-catalyzed process using waste ABE as a raw

17 material can be used for the stable generation of electricity. The emissions of $\mathrm{CO}$ and $\mathrm{SO}_{2}$

18 were reduced for FAME compared with no. 2 diesel oil.

19 Our rough cost-estimation of FAME production, however, reveals that on the basis

20 of $1 \%$ enzyme use, the enzyme cost accounts for $80 \%$ of the total cost, although it is

21 advantageous for the manufacturing process. This means that the enzyme should be

22 reused or the amount should be reduced to improve the economic balance. We are

23 currently attempting to reduce the amount of enzyme added for FAME production and are

24 investigating the improvement of enzyme stability during the transesterification reaction,

25 which is the most important issue to resolve in order to scale-up the lipase-catalyzed 
1 FAME production using waste $\mathrm{ABE}$ as a raw material.

2

\section{5. Conclusions}

The lipase-catalyzed transesterification process is very simple, requiring only two steps compared with the conventional FAME production process. The cost balance,

6 however, remains an obstacle to manufacturing FAME using waste ABE as a raw

7 material. We demonstrated, however, that waste ABE can be used as a raw material for

8 FAME production in a 50-L pilot plant, and the BDF-45 product meets the European

9 specifications defined by pr EN 14214. Exhaust emissions were tested using a generator

10 fueled with BDF-45; SO2 and $\mathrm{CO}$ levels were reduced compared with those obtained

11 when diesel oil was used as the fuel. The results obtained have been used for industrial scale-up of lipase-catalyzed transesterification using waste ABE as a raw material.

\section{Acknowledgments}

This work was performed as a research project for utilizing advanced technologies in agriculture, forestry, and fisheries of the Ministry of Agriculture, Forestry, and Fisheries of Japan. We thank Mr. Yoshirou Hashimoto, the president of Micro Energy Co. Ltd., for fuel-testing the biodiesel produced in this pilot study.

\section{References}

24 Agarwal, A.K., Das, L.M., 2001. Biodiesel development and characterization for use as a fuel in compression ignition engines. Transactions of the ASME 123, 440-447. 
1 Bouaid, A., Diaz, Y., Martinez, M., Aracil, A., 2005. Pilot plant studies of biodiesel

2 production using Brassica carinata as raw material. Catalysis Today 106, 193-196.

3 Clark, S.J., Wangner, L., Schrock, M.D., Piennaar, P.G., 1984. Methyl and ethyl soybean

$4 \quad$ esters as renewable fuels for diesel engines. J. AOCS 61, 1632-1637.

5 Dossat, V., Combes, D., Marty, A., 2002. Lipase-catalysed transesterification of high

6 oleic sunflower oil. Enz. Microb. Technol. 30, 90-94.

7 Du, D., Sato, M., Mori, M., Park, E.Y., 2006. Repeated production of fatty acid methyl

8 ester with activated bleaching earth in solvent-free system. Process Biochem. 41,

$9 \quad 1849-1853$.

10 Fukuda, H., Kondo, A., Noda, H., 2001. Biodiesel fuel production by transesterification 11 of oils. J. Biocsci. Bioeng. 92, 405-416.

12 Kojima, S., Du, D., Sato, M., Park, E.Y., 2004. Efficient production of fatty acid methyl

13 ester from waste activated bleaching earth using diesel oil as organic solvent. J. Biosci. 14 Bioeng. 98, 420-424.

15 Körbitz, W., Friedrich, St., Waginger, E., Wörgetter M., 2003. Worldwide review on 16 biodiesel production, IEA Bioenergy Task 39, Austria Biofuels Inst., Vienna, Austria. 17 Lara, P.V., Park, E.Y., 2003. Lipase-catalyzed production of biodiesel fuel from vegetable 18 oils contained in waste activated bleaching earth. Process Biochem. 38, 1077-1082.

19 Lara, P.V., Park, E.Y., 2004. Potential application of waste activated bleaching earth on 20 the production of fatty acid alkyl esters using Candida cylindracea lipase in organic 21 solvent system. Enz. Microb. Technol. 34, 270-277.

22 Park, E.Y., Mori, M., 2005. Kinetic study of esterification of rapeseed oil contained in 23 waste activated bleaching earth using Candida rugosa lipase in organic solvent 24 system. J. Mol. Catal. B: Enz. 37, 95-100.

25 Schumacher, L.G., Borgelt, S.C., Fosseen, D., Goets, W., Hires, W.G., 1996. Heavy-duty 
1 engine exhaust emission tests using methyl ester soybean oil/diesel fuel blends.

$2 \quad$ Bioresource Technol. 57, 31-36.

3

4 
$1 \quad$ Legends for figures

2

3 Fig. 1. Flow diagram of the transesterification of lipase-catalyzed biodiesel fuel

4 production using waste $\mathrm{ABE}$ as a raw material. Numbers indicate stream lines in Table 1. 5

6 Fig. 2. Effect of reaction temperature on FAME conversion during the lipase-catalyzed

7 transesterification using waste $\mathrm{ABE}$ : (open circle) $15^{\circ} \mathrm{C}$, (closed triangle) $20^{\circ} \mathrm{C}$, (closed

8 circle) $25^{\circ} \mathrm{C}$, (open square) $35^{\circ} \mathrm{C}$, (open triangle) $45^{\circ} \mathrm{C}$, (closed square) $55^{\circ} \mathrm{C}$.

9

10 Fig. 3. Comparison of engine exhaust emission between BDF-45 (solid lines) and diesel 11 oil (dotted lines). 


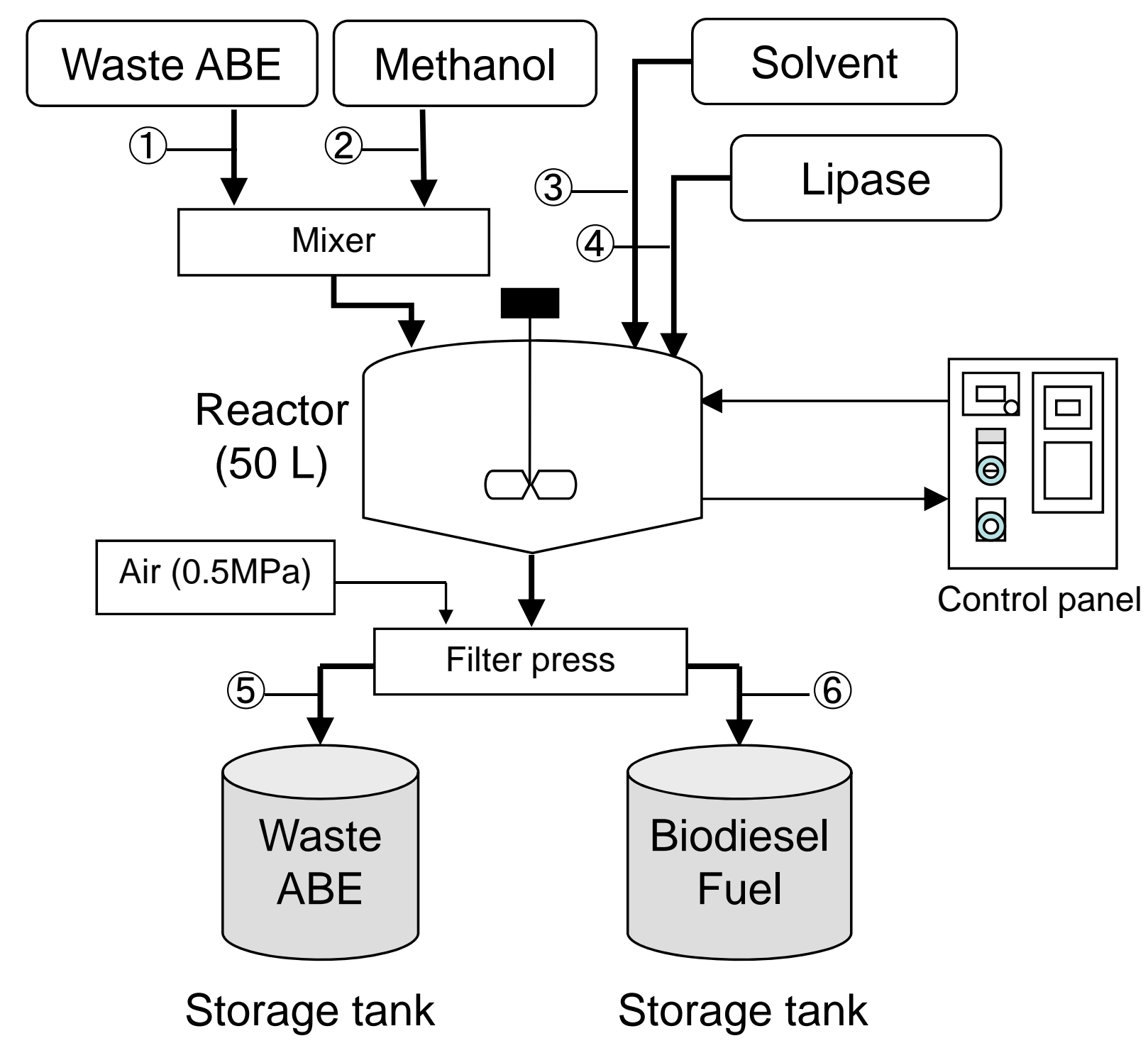




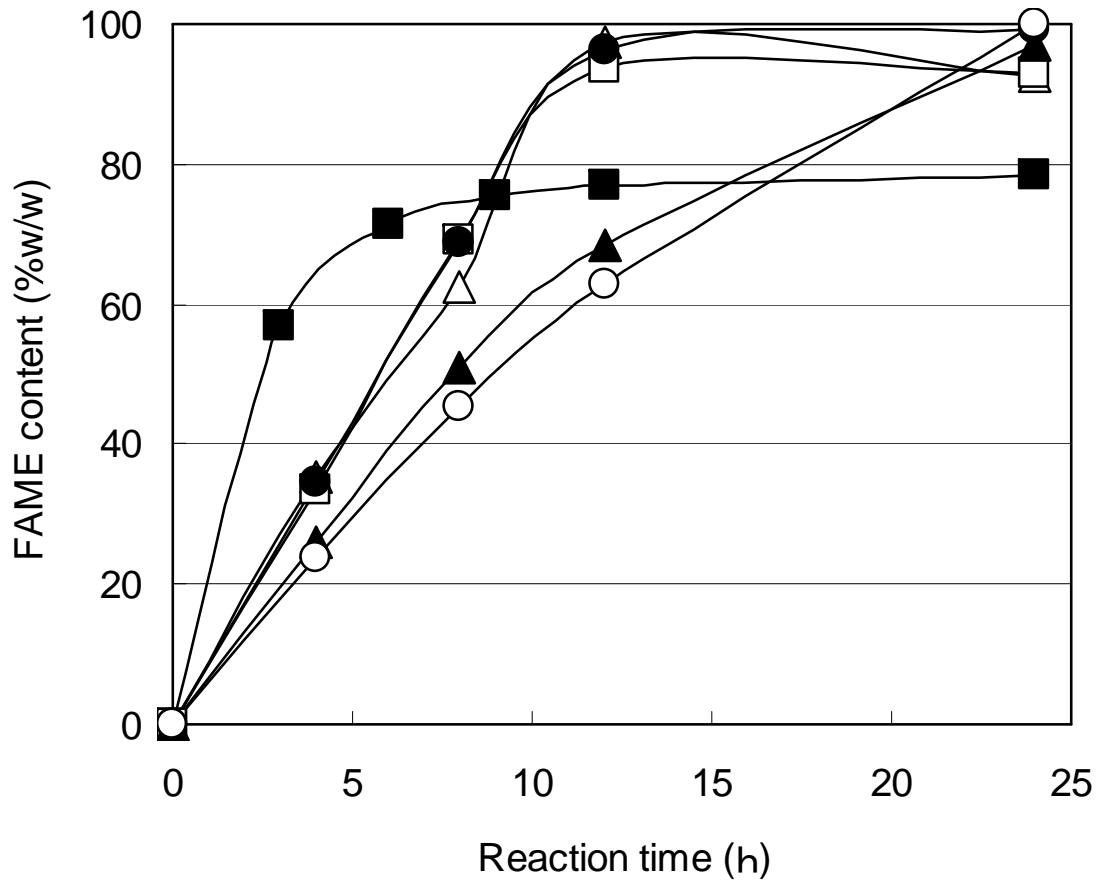


Fig. 3, Park et al.
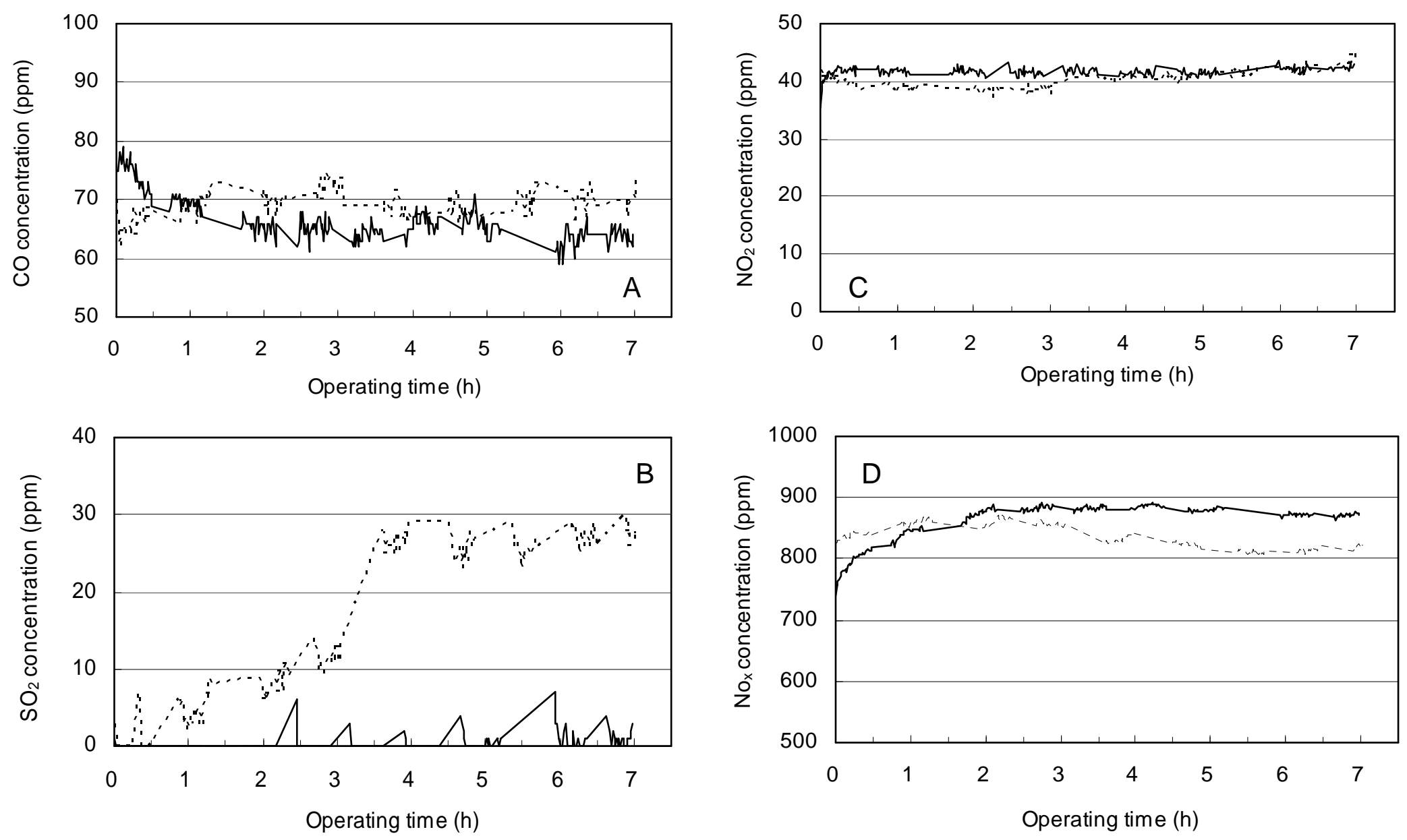
Table 1

Main characteristics of BDF-45 and BDF-35 obtained from waste ABE with enzyme as a catalyst, for use as a biodiesel fuel

\begin{tabular}{|c|c|c|c|c|c|c|c|}
\hline No & 1 & 2 & 3 & 4 & 5 & 6 & $\begin{array}{c}\text { EU Draft standard } \\
\text { prEN } 14214\end{array}$ \\
\hline \multicolumn{8}{|l|}{ Reaction conditions } \\
\hline Origin of waste $\mathrm{ABE}$ & Palm & Palm & Palm & Palm & $\begin{array}{c}\text { Rapeseed } \\
\text { oil }\end{array}$ & Palm & \\
\hline Solvent & Diesel oil & Diesel oil & Diesel oil & Diesel oil & Diesel oil & Kerosene & \\
\hline Enzyme amount (\%) & 1 & 1 & 1 & 0.1 & 1 & 0.1 & \\
\hline Reaction temperature $\left({ }^{\circ} \mathrm{C}\right)$ & 15 & 25 & 45 & 25 & 25 & 25 & \\
\hline Final product & & & $\mathrm{BDF}-45^{*}$ & & & $\mathrm{BDF}-35^{\dagger}$ & \\
\hline \multicolumn{8}{|l|}{ Properties of biodiesel fuel } \\
\hline Density at $15^{\circ} \mathrm{C}\left(\mathrm{kg} / \mathrm{m}^{3}\right)$ & 859.6 & 846.5 & 849.7 & 849.2 & 850.2 & 823.7 & $860-900$ \\
\hline Distillation range $\left({ }^{\circ} \mathrm{C}\right) 90 \%$ & 335.0 & 339.0 & 340.0 & 345.0 & 342.0 & 332.0 & - \\
\hline Flash point $\left({ }^{\circ} \mathrm{C}\right)$ & 79 & 75 & 75 & 78 & 69 & 51 & $\begin{array}{c}\text { Minimum 120, } \\
\text { Minimum } 59 \text { (JIS } \\
\text { K 2204) }\end{array}$ \\
\hline
\end{tabular}




\begin{tabular}{|c|c|c|c|c|c|c|c|}
\hline Pour point $\quad\left({ }^{\circ} \mathrm{C}\right)$ & 2.5 & 0.0 & 0.0 & 0.0 & -10.0 & -22.5 & - \\
\hline Cloud point $\left({ }^{\circ} \mathrm{C}\right)$ & 0 & -1 & 0 & -1 & -12 & 2 & - \\
\hline $10 \%$ residual carbon amount (\% wt) & 0.18 & 0.18 & 0.19 & 0.21 & 0.48 & 0.13 & Maximum 0.3 \\
\hline Cetane number & 55.5 & 56.5 & 55.3 & 56.6 & 53.9 & 46.8 & Minimum 51.0 \\
\hline Kinematic viscosity at $30^{\circ} \mathrm{C}\left(\mathrm{mm}^{2} / \mathrm{s}\right)$ & 4.74 & 4.46 & 4.76 & 4.71 & 4.71 & 2.38 & - \\
\hline Sulfur (ppm) & 4 & 4 & 4 & 4 & 5 & 4 & Maximum 10.0 \\
\hline Calorific value (kJ/kg) & 42650 & 43240 & 42990 & 42490 & 42950 & 43140 & - \\
\hline Color (ASTM) & Below 1.0 & Below 1.0 & L1.5 & 1.0 & 2.0 & Below 1.0 & \\
\hline
\end{tabular}

${ }^{*}$ Mixture of FAME and diesel oil at ratio of $45: 55$.

${ }^{\dagger}$ Mixture of FAME and kerosene at ratio of $35: 65$ 